\title{
GIBaren aurkako txertoaren bila
}

\section{(In search of a vaccine against HIV)}

\author{
Johana Torralba ${ }^{1,2}$, Estibaliz Goikoetxea $^{2}$, Beatriz Apellaniz ${ }^{1 *}$ \\ ${ }^{1}$ Biofisika Institutua (CSIC, UPV/EHU) eta Biokimika eta Biologia Molekularreko \\ Saila, Zientzia eta Teknologia Fakultatea (UPV/EHU) \\ ${ }^{2}$ Egile hauen partaidetza berbera izan da \\ *beatriz.apellaniz@ehu.eus
}

DOI: 10.1387/ekaia.17854

Laburpena: GIB birusa, giza historian zehar gertatu den pandemiarik hilgarrienetariko baten eragilea da, HIESa alegia. Nahiz eta azken urteetan HAART terapia antirretrobiralari esker heriotza tasa asko murriztu den, infekzio berrien kopurua etengabe emendatzen ari da. Hori dela eta, badirudi pandemiari azkenik amaiera eman ahal izateko txerto prebentibo baten garapena izan daitekeela jokaera eraginkorrena. Hala ere, birusak garatu dituen estrategia natural desberdinek eta immunizazioz sortu nahi diren antigorputz neutralizatzaileen ezaugarri bereziek oso zaila egiten dute infekziotik babestuko lukeen txertoaren garapena. RV144 entsegu klinikoaren eraginkortasun apalek eta espektro zabaleko antigorputz neutralizatzaileekin immunizazio pasiboz lorturiko emaitzek iradokitzen dute hurbilago gaudela txerto eraginkor baten garapena lortzetik. Orain arte hainbat txerto mota erabili diren arren, emaitza onik ez da lortu. Hala ere, sakon aztertzen ari da bai immunogeno naturalen egitura, bai immunogenoak ezagutzen dituzten antigorputzen egitura, eta badirudi, besteak beste, ikerketa horiek bide berriak irekiko dituztela txerto berrien diseinuan.

Hitz gakoak: GIB, txertoa, antigorputz neutralizatzaileak, Env fusio-glukoproteina.

Abstract: HIV is the causative agent of one of the most lethal pandemics in human history, AIDS. Although in recent years HAART therapy has considerably reduced death rate, new infections keep arising. Therefore, a preventive vaccine remains the most promising tool to end the pandemic. However, the virus has developed many natural strategies to evade the immune system and, moreover, the special characteristics of the neutralizing antibodies that a vaccine aims to elicit, makes vaccine design extremely challenging. The efficiency of the RV144 clinical trial and the promising results obtained by passive immunization with broadly neutralizing antibodies suggest that the objective of obtaining an effective vaccine is closer. Until now, a myriad of vaccine strategies have been attempted but the expected results have not been yet ob- 
tained. However, the thorough research on the structure of the viral immunogens and the antibodies that recognize them might pave the way for the design of future effective immunogens.

Keywords: HIV, vaccine, broadly neutralizing antibodies, Env fusion glycoprotein.

\section{SARRERA}

Osasunaren Mundu Erakundeak dituen datuen arabera 37 milioi gizaki inguru daude gaur egun HIESa eragiten duen GIB birusaz kutsatuta (1a irudia) eta horietatik, soilik erdiak du terapia antirretrobirala jasotzeko aukera. Gainera, 1981etik, alegia HIESaren lehenengo kasuak deskribatu zirenetik, infektatuen kopuruak etengabe egin du gora, urtero milioika gizaki infektatzen direlarik (1b irudia). Hala ere, azken urte hauetan $\% 45$ murriztu da gaixotasunarekin loturiko heriotza tasa (1c irudia), eta horrek esan nahi du terapia antierretrobiralek hobera egin dutela eta medikamentuaren eskuragarritasunak ere gora egin duela [1].

A

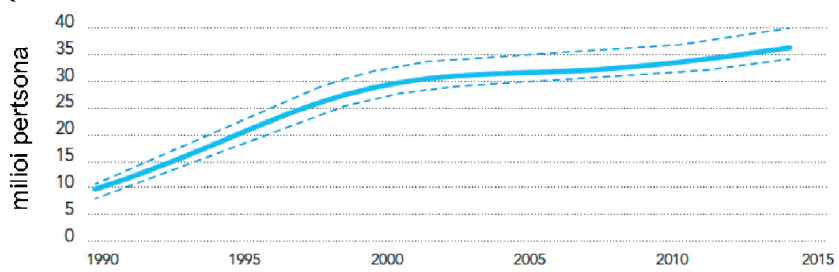

GIBak jota bizi diren gizakiak 2015ean: 36.7 milioi (34.0 - 39.8 milioi)

B

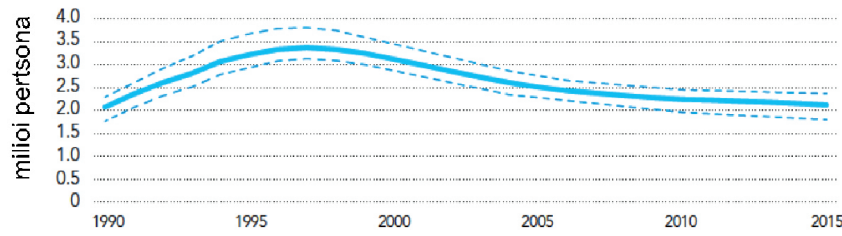

GIB infekzio berriak 2015ean: 2.1 milioi $(1.8-2.4$ milioi)

$\mathrm{C}$

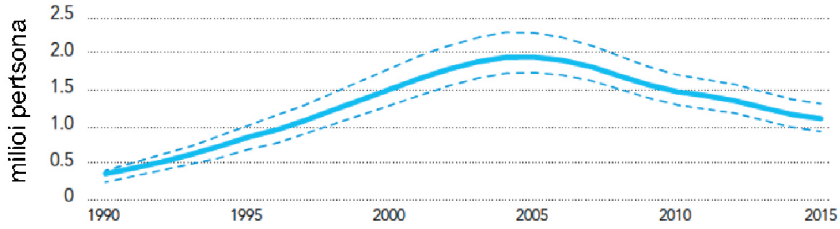

GIB infekzioaren ondorioz

hildakoen kopurua.

Guztira: 35 milioi

2015ean: 1.1 milioi (940.000-1.3 milioi)

1. irudia. GIBaren eraginaren ikuspegi historikoa [1]. (A) GIBak jota bizi diren indibiduoen kopuruak gora egin du azken urteetan, urtero GIBak eragindako infekzio berri ugari gertatzen direlako (B) eta HIESak eragindako heriotza kopuruak behera egin duelako terapia antirretrobiralaren eraginkortasunari esker (C). 
Egun, erreferentziazko terapia HAART (ingelesetik, Highly Active Antiretroviral Therapy) deituriko erretrobirusen kontrako eraginkortasun handiko tratamendua da, birusaren hainbat ituren aurkako farmako-konbinazioa alegia $[2,3]$.

Terapia honen bitartez, birusaren erreplikazioa kontrola daiteke, baina tratamenduak ez du birusa guztiz ezabatzen, infektatutako $\mathrm{T}$ zelulak indibiduoetan jarraitzen baitute. Beraz, pandemia honi amaiera eman ahal izateko, nahitaezkoa da infekzio berriak saihestea eta hortaz, oso premiazkoa da GIB birusaren aurkako txerto prebentibo baten garatzea. Berrikusketa honetan, labur aztertuko dira birus honen aurkako txerto baten garapena lortzeko dauden erronkak, historian zehar egindako saiakera garrantzitsu desberdinak eta gai honen inguruan lortu izan diren aurrerakuntzak.

\section{GIB BIRUSA}

GIB birusa Retroviridae familiaren Lentivirus generoaren barnean sailkatuta dago. Lipido-bigeruza batez inguraturik dago eta $9 \mathrm{~Kb}$-ko kate bakuneko bi RNA molekula berdinez osatutako genoma dauka. Bere 9 geneetatik, hiru dira garrantzitsuenak: gag, pol eta env. Gag genea, egiturazko proteinen aitzindaria da: birusaren matrizea, kapsidea eta nukleo-kapsidea osatuko ditu proteina horrek; pol geneak, proteasa, alderantzizko transkriptasa eta integrasa entzimak kodetzen ditu; azkenik, env geneak, gainazalean dagoen gp160 fusio glukoproteina (Env) kodetzen du. Gainontzeko geneak, erregulazioaren eta birulentziaren erantzule dira.

Birusak kodetzen dituen proteinen artean, oso garrantzitsua da txerto profilaktiko bat garatzearen ikuspuntutik Env glukoproteina, agerian dagoen proteina bakarra, eta hortaz, sistema immuneak ezagutu dezakeen antigeno bakarra (2. irudia) [4]. Gp160 aitzindaria, proteolisi mugatuaren bitartez bi azpiunitatetan banatzen da: gp120 eta gp41 (2. irudia). Env konplexua hiru gp120 azpiunitatez eta hiru gp41 azpiunitatez osaturiko hetero-dimeroen trimero bat da [5, 6]. Lehenengoa, gp120, itu-zelula zehazten duen gainazaleko proteina da eta bigarrenak, gp41-k, mintza zeharkatzen du eta Env konplexua birusaren lipido-estalkian ainguratzen du; halaber, itu-zelula eta birusaren mintzen fusioaren eragilea da. Fusio prozesuan, lehenik eta behin, gp120 azpiunitatea itu-zelularen CD4 hartzaileei lotzen zaie, eta horrela CCR5 edo/eta CXCR4 kohartzaileekiko lotura ahalbidetzen du (2. irudia).

Lotura honek zenbait konformazio-aldaketa eragingo ditu gp41 azpiunitatean, bi mintzen arteko fusioa ahalbideratuz. Alde batetik, itu-zelularen mintzean txertatuko da gp41 azpiunitatearen amino muturrean kokatzen den fusio peptidoa (FP); beste aldetik, mintza desegonkortzen lagundu lezake eskualde jakin batek, alegia mintza zeharkatzen duen domeinuaren 
A

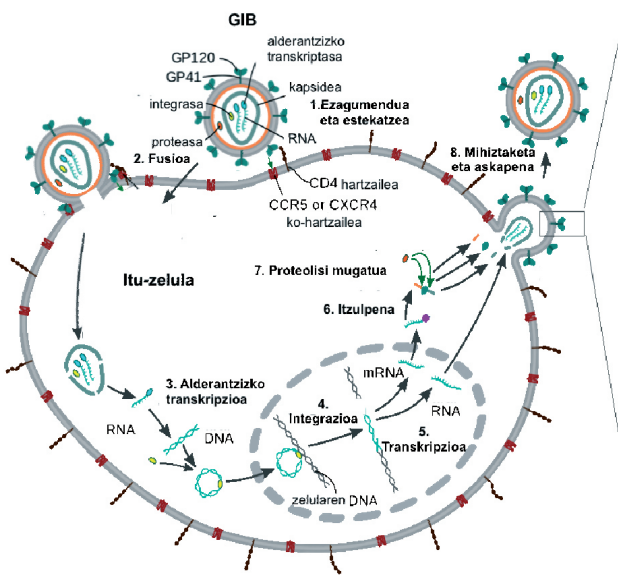

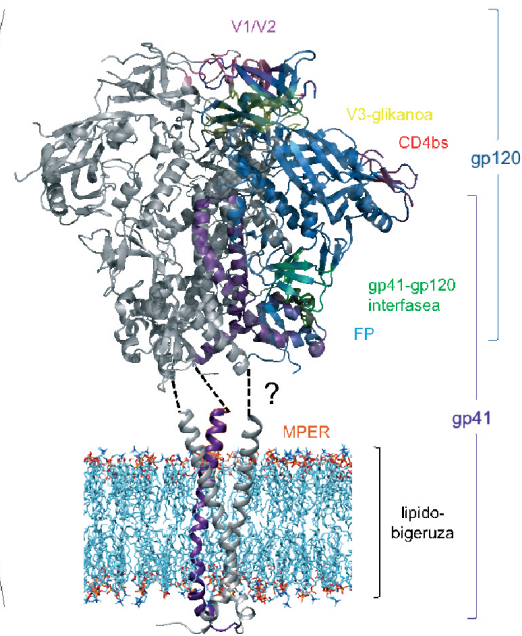

2. irudia. (A) GIB birusaren infekzio-zikloaren urratsak. Lehenik eta behin, ituzelularen eta birusaren arteko ezagumendua (1) eta estekatzea gertatzen da (2) eta birusak bere material genetikoa barneratzen du infektatutako zelulan. Gero, alderantzizko transkriptasaren bitartez (3), birusaren RNA DNA bihurtzen da eta integrasaren bitartez itu-zelularen genoman txertatzen da (4). Era honetan, birusak bere menpe hartzen du zelula eta honek birioi berriak sintetizatzen ditu $(5,6)$. Partikula birikoen prozesaketa proteolisi mugatu bidez gertatzen da (7). Ondoren, birusaren proteinen mihiztaketa gertatzen da eta azkenik, gemazio bidez gauzatzen da birus berrien askapena (8). (Jmarchn egilearen iruditik eraldatua, CC BY-SA 3.0 lizentzia) [13]. (B) Env konplexuaren egituraren irudikapena eta bertara bideratzen diren antigorputz neutralizatzaileek ezagutzen dituzten epitopoak. Trimeroaren egitura sekundarioa zintekin, eta Env konplexuaren azalera irudikatu dira. Hain zuzen, gp120 urdin ilunez irudikatzen da eta gp41 morez (ulermena errazteko, gp120-gp41 protomero bakarraren egitura sekundarioa koloreztatu da). Halaber, bNab-ek (ingelesetik, Broadly Neutralizing Antibody) ezagutzen dituzten gp120 eta gp41 azpiunitateen gune kritikoak [14] koloreztaturik ageri dira; gp41 azpiunitatean MPER domeinua laranjaz eta fusio peptidoa urdinez; gp41 eta gp120 azpiunitateen arteko interfasea berdez; gp120 azpiunitatean CD4 hartzailearen lotura gunea gorriz, V3 glikanoa horiz eta V1/V2 begizta aldakorrak arrosaz. 5FUU pdb kodea [15] erabili da ektodomeinua irudikatzeko eta 5GHW [16] eta 5JNY [17] kodeak MPER eta TMD eremuentzako, hurrenez hurren.

aurretik kokatzen den eskualdeak (MPER, ingelesetik, Membrane Proximal External Region). Horrela, itu-zelularen eta birusaren mintzen arteko fusioa erraztu egiten da eta era honetan, birusak bere material genetikoa itu-zelulan barneratuko du [7-10].

Azkenik, birusak, infektatzen duen zelula ostalaritik abiatuta lortutako lipido-mintza du. Alde batetik, lipido-estalki hau garrantzi handiko egitu- 
ra-osagaia da eta beste aldetik, infekzioa gerta dadin, ezinbestekoa da bere osaketa espezifikoari eustea. Oso aipatzekoa da lipido-estalki honek duen $\%$ 45eko kolesterol kontzentrazioa [11], infekzioa murrizten baita kolesterol kontzentrazioa behera egiten badu [12].

\section{TXERTO MOTAK}

Historian zehar, medikuntza arloak izan duen aurrerakuntzarik handienetarikoa izan da txertoa. Osasunaren Mundu Erakundeak dituen datuen arabera, txertoek, urtero, 2-3 milioi heriotza saihesten dituzte. Gainera, txertoei esker, baztanga gaixotasuna guztiz desagerraraztea lortu da eta desagertzear daude beste zenbait giza gaixotasun, esaterako poliomielitisa eta elgorria [18]. Txerto bat eraginkorra izan dadin, hurrengo baldintzak bete behar ditu: i) immunogenikoa izatea, ii) espezifikoa izatea, iii) babesa hornitzea eta iv) babes hau denboran iraunkorra izatea. Alde batetik, patogeno bat dagoelarik, gure organismoak bi immunitate-erantzun jartzen ditu abian: berezko immunitate-sistema eta immunitate-sistema egokitzailea. Azken honek bi erantzun mota eman ditzake: zelulek bideraturikoa ( $\mathrm{T}$ linfozitoen bidezkoa) eta erantzun humorala (B linfozitoek ekoizten dituzten antigorputzen bidezkoa, alegia). Txerto prebentibo batek piztu behar ditu bi erantzun mota hauek; lehenik eta behin, antigorputzen bidez birusaren infekzioa blokeatzen du eta ondoren, zelulen bitartez jada infektatuak dauden zelulak ezabatu [19]. Beste aldetik, txertoen bitartez piztuko den erantzuna birusaren eskualde jakin batzuetara espezifikoki bideratua egon beharko da; hau da, immunitate-sistemak antigeno jakin batekiko diskriminazio-ahalmena izan behar du erantzun egoki eta ahaltsua lortzeko. Behin eskualde hauek ezagututa, jakina, birusaren funtzioa oztopatu egin beharko du. Azkenik, oso garrantzitsua da oroimenezko B eta T zelulak garatzea, birusarekin kontaktua izatekotan birusetik babestua egoteko [20].

Zenbait txerto mota daude, baina orokorrean bi talde nagusitan sailka daitezke; alde batetik, organismo osoak eta bestetik, organismo hauen zatiak, antigeno deritzenak. Lehenengo taldean, badaude txerto inaktibatuak (hilda dauden organismoak) eta indargabetuak (hainbat tratamenduren bitartez birulentzia galdu duten baina bizirik dauden organismoez osaturikoak). Bigarren taldean aldiz, errekonbinazio bidez ekoiztutako organismoaren antigeno jakin batzuk; hauek besteak beste, proteina, DNA edo birusak imitatzen dituzten partikulak (VLP, ingelesetik, Viral Like Particles) izan daitezke [21]. Bigarren taldeko txertoen abantailak bi dira; alde batetik, sistema immunearen erantzuna pizten duten patogenoaren molekulak normalean gutxi direnez, errazagoa da estrategia «minimalista» honen bitartez autoimmunitate-erreakzioak ekiditea. Beste aldetik, immunitateerantzuna eskualde espezifikoetara zuzentzen da [19]. Hala ere, azpiunitate-txerto hauen immunogenikotasuna asko murriztu ohi denez, beharrez- 
koa gertatzen da immunitate-sistema estimulatuko duten beste molekula batzuen (adjubanteen) erabilera. Beraz, immunogeno egokia aurkitzeaz gain, adjubante konbinazio egokia ere aurkitu behar da txerto eraginkor baten garapenean. Izan ere, ikaragarria da eskuragarri dauden adjubanteen kopurua, baina oraindk luze joko du immunogeno-adjubante konbinazio egokia zein den ezagutzera iristeak [22].

\section{GIB-AREN AURKAKO TXERTOAREN ERRONKA}

Aurretiaz esan bezala, Env konplexua agerian dagoen birusaren proteina bakarra izatearekin batera, infekzioa hasteko ezinbestekoa da. Bi ezaugarri hauek direla eta, aukerako immunogenoa da GIB birusaren aurkako txerto eraginkor bat lortzeko. Badirudi Env konplexua erabiltzea dela txerto prebentiboa lortzeko bidea, baina hala ere, ez da oraindik txerto profilaktiko bat garatzea lortu [23]. Izan ere, birusak immunitate-sistematik ihes egiteko zenbait teknika garatu ditu [24]. Horien artean, aipatzekoa da birusaren mutazio tasa altua, alderantzizko transkriptasaren efizientzia baxua eta akatsak zuzentzeko jarduera eza [25]. Honen ondorioz, birusak izugarrizko aldakortasun genetikoa du, baita birusak bere funtzioak betetzeko ezinbestekoak dituen guneetan ere, Env konplexua barne [26]. Honetaz bestalde, Env konplexuaren kopia gutxi daude birusean (soilik 8-14 fusio-proteina inguru birus bakoitzean) eta are gehiago, horietatik asko ez dira funtzionalak izaten baina bai oso immunodominanteak $[27,28]$. Ondorioz, immunitate-sistemaren erantzuna Env ezfuntzionaletara zuzendu ohi da, eta ondorioz ez zaio infekzioari eragiten. Gainera, funtzionalak diren Env konplexuak birusak garatutako beste hainbat metodoren bitartez babestuta egoten dira [29]. Alde batetik, gp120 azpiunitatean zenbait antigorputzen lotura saihesten duen hesi lodi bat dago, glikanoz osatua [26]. Beste aldetik, konformazio-ezkutaketa gertatzen da; izan ere, kontserbatuta dauden zenbait gune ez dira agerian egoten, gp120 eta CD4 hartzailearen arteko loturak eragiten duen konformazio-aldaketa gertatu arte [30]. Horretaz gain, funtzionalak diren Env konplexuak immunodominanteak diren begizta aldakorrez inguraturik egon ohi dira, eta konplexuak berak eragin lezakeen immunitate-erantzuna oztopatu egiten da.

Hala eta guztiz ere, itu-zelularen infekziorako ezinbestekoak diren sei gune kontserbatu identifikatu dira Env konplexuan (2b irudia): gp120 azpiunitateko CD4 hartzailearen lotura-gunea, V1/V2 begizta aldakorrak eta V3-glikanoa, gp120 eta gp41 azpiunitateen arteko interfasea, eta gp41 azpiunitatearen fusio peptidoa (FP) eta MPER domeinua [14].

Infektatuen \% 1 elitezkotzat jotzen dira espektro zabaleko aktibitate neutralizatzaile ahaltsua duten antigorputzak sortzen dituztelako; be- 
ren antigorputzak, aipatutako gune kritiko hauetara zehazki zuzenduta daude [31]. Antigorputz hauek, infekzioa gertatu eta zenbait urtera agertu ohi dira; horrek esan nahi du birusekin batera ko-eboluzionatzen dutela antigorputzek [32].

Zoritxarrez, bNab hauek beraiek ezartzen duten selekzio-presioa dela eta, elitezko neutralizatzaileak diren gizabanakoek dituzten birus-anduiak erresistenteak bilakatzen dira bNab-ekiko, eta hortaz, gaixotasuna pairatzen jarraitzen dute.

Gainera, gaur egun ezagutzen diren bNab-ek oso ezaugarri bereziak dituzte: mutazio somatiko asko, poli-erreaktibitatea eta askotan baita auto-erreaktibitatea eta CDR-H3 begizta luzeak ere [32]. Ezaugarri hauen ondorioz, antigorputz hauen ekoizpena ostalariaren immunitate-sistemaren tolerantzia-kontrolen bidez mugatuta egon daiteke [33]. Hala ere, bNab-en existentziak berak aditzera ematen du infekziotik babestuko lukeen txerto bat gara daitekeela. Gainera, bNab-ak zuzenean txertatuz, gizakiak ez diren primateetan lortu da SHIVak (ingelesetik, Simian-Human Immunodeficiency Virus izenekoak) eragindako infekzioaren aurkako babesa [34] eta baita humanizaturiko saguetan GIBak eragindakoa ere [35]. Horrek esan nahi du bNab-ak erabilgarriak direla ziur aski. Beraz, txertoen bidez antigorputz eraginkor eta berezi hauen sintesia piztea da helburua.

\subsection{GIBaren aurkako txerto motak}

GIB birusaren identifikazioa egin zenetik, 30 urte baino gehiago igaro dira eta 250 entsegu kliniko baino gehiago egin dira, baina hala ere oraindik ez da birus honen aurkako txerto eraginkorrik lortu. Lehenengo txertoen saiakerak birus indargabetuetan oinarritu ziren, txerto mota hauek arrakastatsuak izan baitziren beste birus batzuen aurka. Hala ere, GIBaren kasuan ez ziren esperotako emaitza onak lortu SIV (ingelesetik, Simian Immunodeficiency Virus) ereduan oinarritutako entseguetan. Tximinoetan adibidez, ikusi izan da SIV indargabetuan oinarritutako txertoa tximinoei jaioberrian emanez, epe luzean zenbaitek HIESa garatzen zutela [36]. Izan ere, erretrobirusaren mutazio tasa altua dela eta, eboluzionatu eta berriro ere birus patogeniko bilaka daiteke [31].

Historian zehar egin diren entsegu guztietatik soilik sei heldu dira eraginkortasun klinikoko fasera (IIB/III fasera hain zuzen) (1. taula). Birus indargabetuen arriskua ikusita, hurrengo saiakeretan birus osoak erabili beharrean, birusaren azpiunitate errekonbinanteak erabili izan ziren. Honen adibide dira gp120 monomeriko eta disolbagarria immunogeno moduan duten txertoak: VAX003, B kladoko sekuentzia erabili eta \% 0,1 eko eraginkortasuna izan zuena [37], eta VAX004, B eta E kladoetako sekuentziak erabili eta \% 6ko eraginkortasuna izan zuena [38]. Nahiz eta entsegu haue- 
tan andui autologoen aurkako antigorputzen ekoizpena piztu, andui heterologoen aurka ez zen antigorputzik detektatu; hau da, sortutako antigorputzak ez ziren bNab-ak izan.

1. taula. Eraginkortasun klinikoa ebaluatzeko faseetara heldu diren HIESaren aurkako txertoak.

\begin{tabular}{|c|c|c|c|c|c|c|}
\hline Entsegua & Data & Populazioa & Fasea & Txerto mota & $\begin{array}{l}\text { Esperotako } \\
\text { erantzuna }\end{array}$ & Emaitza \\
\hline VAX004 & $\begin{array}{l}1988- \\
2003\end{array}$ & MSM a & III & rgp120 (B kladoa) & Humorala & $\begin{array}{l}\text { bNab-en eran- } \\
\text { tzun ahula }\end{array}$ \\
\hline VAX003 & $\begin{array}{l}1999- \\
2003\end{array}$ & $\begin{array}{l}\text { Droga kon- } \\
\text { tsumitzai- } \\
\text { leak }\end{array}$ & III & $\begin{array}{l}\text { rgp120 (B, E kla- } \\
\text { doak) }\end{array}$ & Humorala & $\begin{array}{l}\text { bNab-en eran- } \\
\text { tzun ahula }\end{array}$ \\
\hline Step & $\begin{array}{l}2004- \\
2007\end{array}$ & MSM & $\mathrm{IIb}$ & $\begin{array}{l}\text { rAd5 (gag/ pol/nef) } \\
\text { (B kladoa) }\end{array}$ & Zelularra & $\begin{array}{l}\text { Infekzioa pai- } \\
\text { ratzeko arris- } \\
\text { kuaren emen- } \\
\text { daketa }\end{array}$ \\
\hline Phambili & $\begin{array}{l}2007- \\
2007\end{array}$ & $\begin{array}{l}\text { Heterose- } \\
\text { xualak }\end{array}$ & IIb & $\begin{array}{l}\text { rAd5 (gag/ pol/nef) } \\
\text { (B kladoa) }\end{array}$ & Zelularra & $\begin{array}{l}\text { Step entsegua- } \\
\text { ren antzeko } \\
\text { emaitza }\end{array}$ \\
\hline RV144 & $\begin{array}{l}2003- \\
2009\end{array}$ & $\begin{array}{l}\text { Heterose- } \\
\text { xualak }\end{array}$ & III & $\begin{array}{l}\text { Canarypox (gag/ } \\
\text { pol/nef) +rgp } 120 \\
(B, \text { E kladoak) }\end{array}$ & $\begin{array}{l}\text { Zelularra } \\
\text { eta humo- } \\
\text { rala }\end{array}$ & $\begin{array}{l}\% 31,2-\mathrm{ko} \\
\text { eraginkorta- } \\
\text { suna infek- } \\
\text { zioaren pre- } \\
\text { bentzioan }\end{array}$ \\
\hline HVTN 505 & $\begin{array}{l}2009- \\
2015\end{array}$ & MSM & IIb & $\begin{array}{l}\text { DNA plasmidoa } \\
\text { (gag/pol/nef/env) + } \\
\text { rAd5 (gag/pol/env) } \\
\text { (A, B, C kladoak) }\end{array}$ & $\begin{array}{l}\text { Zelularra } \\
\text { eta humo- } \\
\text { rala }\end{array}$ & $\begin{array}{l}\text { Ez eraginko- } \\
\text { rra }\end{array}$ \\
\hline
\end{tabular}

Antigorputz neutralizatzailerik garatu ez zenez, hurrengo bi entseguak $\mathrm{T}$ linfozitoen erantzuna bilatzea izan zuten helburu; hain zuzen, Step eta Phambili. Bi kasu hauetan, immunogenoa gag, pol eta nef geneak daramatzan Ad5 adenobirus indargabetua gertatu zen. Txerto honek, T linfozitoen erantzuna pizteko gai izan zen arren, ez zuen birus kantitatea murriztu, ezta bNab-en ekoizpena piztu [39].

Soilik T linfozitoen erantzuna pizteko txertoen eraginkortasun falta ikusita, HVTN505 entseguan, erantzun zelularra eta antigorputzen bidezko erantzuna bilatu izan zen. Horretarako, lehenik eta behin, gag/pol/nef/env proteinak kodetzen zituen DNA txertoa erabili zen, eta jarraian, Step eta 
Phambilin erabilitako Ad5 bektorea. Txerto honek B eta T linfozitoen erantzunak eragin zituen arren, ez zen infekzioaren murrizpenik lortu [40].

Azkenik, RV144 entseguan, immunitate-sistema egokitzailearen bi bideak (zelulek bideraturikoa eta humorala) pizteko helburu berbera hartuta, bi txertoen konbinazioa erabili zen. Alde batetik, env, gag eta pol geneak zeramatzaten hegaztiak infektatzen dituen birus bat, eta bestetik, VAX003 entseguan erabilitako proteina errekonbinantea. Orain arte hau izan da GIBaren infekzioa ekiditeko arrakasta izan duen entsegu bakarra. Izan ere, $\%$ 31,2ko eraginkortasuna erdietsi zen, bNab edo erantzun zelular indartsurik eragin ez bazen ere [41].

\subsection{Aurrerakuntzak eta etorkizunerako jarraibideak}

Gaur egun, GIBaren aurkako txertoaren helburu nagusietarikoa da birusaren infekziotik babestuko luketen antigorputz neutralizatzaileen sintesia piztea.

Xede hau lortzeko hauxe da estrategia erabiliena: Env konplexuan dauden epitopo kontserbatuen eta bertara lotzen diren bNab-en egituren analisiek gidatutako txertoen diseinua.

Honetan oinarrituta, hainbat diseinu-estrategia erabiltzen ari dira. Alde batetik, Env trimero natiboan oinarritutako txertoen garapena eta bestetik, bNab-en epitopo minimalistak. Bioingeniaritzaren aurrerabideek laguntza eman dute Env natiboak duen egitura (2b irudia) ahalik eta hobekien imitatzen duten trimero disolbagarrien diseinu eta sintesian; horren adibide da SOSIP deituriko trimero disolbagarria. Egitura honek Env konplexuaren ektodomeinua du eta hiru azpiunitate solugarriez osaturik dago. Hain zuzen, solugarri bihurtu ahal izateko gp41en MPER 664. aminoazidotik moztu da, transmintz domeinua eta buztan zitoplasmatikoa kenduz. Gp41 eta gp120 azpiunitateak disulfuro baten bidez kobalenteki lotu dira eta egitura egonkortzeko gp41 azpiunitatearen 559. kokapenean isoleuzinaren ordez prolina bat jarri da [5]. Egindako immunogenizitate eta antigenizitate saioek aditzera ematen dute egitura hau gai dela neutralizatzaileak diren antigorputzen ekoizpena pizteko. Hala ere, sortutako antigorputzek ez dute birusaren espektro zabala neutralizatzen [5], eta hortaz, trimero honen espezifizitatea emendatzera zuzendu dira ahaleginak. Espezifizitatea handitzeko, neutralizatzaileak ez diren antigorputzen ezagumendua murriztu nahi izan da, gp120 azpiunitateen artean disulfuro lotura gehiago gehituz edo immunodominantea den eta antigorputz ezneutralizatzaileen sintesia pizten duen V3-glikanoaren ezagumendua oztopatuz. Horrela, epitopo garrantzitsuen immunogenizitatea hobetu egin da [5]. Esan beharrekoa da egitura honek faltan duen MPER-TMD domeinuak antigenizitatea modula dezakeela [17], eta domeinu hauek mantentzea beharrezkoa izan litekeela bNab-ak sortzeko. 
SOSIP trimero solugarria, modu isolatuan erabiltzeaz gain, nanopartikuletan [42] edo liposometan [43] txertatu izan da bere immunogenizitatea hobetzeko helburuarekin. Lehenengo kasuaren adibide gisa, ikusi izan da B linfozitoen erantzun indartsua eragin dezaketela ferritina proteinaz osatuta dauden eta 20 fusio-proteina dituzten nanopartikulek. Liposoma sintetikoen kasuan bestalde, SOSIP trimeroa egonkortzeko, trimeroaren karboxil mutur bakoitzean histidina etiketa bat jarri da. Liposoma hauetan, ikusi da SOSIPa dentsitate altuan eta era ordenatuan jarrita, Env konplexu natiboak dituen ezaugarriak mantentzen direla eta gainera, B linfozitoak trimeroa era solugarrian aurkeztuta baino hobeto aktibatzen direla. Hala ere, ez nanopartikulak ezta liposomak ere, ez dira gai izan espektro zabaleko antigorputz neutralizatzaileen sintesia pizteko.

Env konplexua imitatzen duten trimeroen esparruan beti ere, egitura disolbagarriak erabili beharrean, VLPetan adieraztea da beste estrategia bat, infekzio naturalean gertatzen den egoera hobeto antzeratuko delakoan. Hala ere, partikula hauek sistema immunea pizteko gai diren arren, estrategia honek ez ditu esperotako emaitzarik eman, neutralizatzaileak ez diren antigorputzen ekoizpena pizten baitute. Izan ere, mintzean Env ezfuntzional ugari adierazten dira. Hala ere, ikusi da arazo hau konpon daitekeela Endo H, kimotripsina eta halako entzimen bitartez Env ezfuntzionalak mintzetik kenduz eta, aldiz, Env funtzionalak mintzean mantenduz [44]. Modu honetan erantzun immunea trimero funtzionaletara bideratuta, nabarmen murriztu ahal da antigorputz ezneutralizatzaileen kopurua [45].

Beste estrategia batzuek proposatu dute antigorputzak ezagutzen dituzten segmentu jakin horiek bakarrik erabil litezkeela immunogeno moduan, Env konplexu osoa erabili beharrean. Horrela, eremu immunodominanteak saihestu daitezke eta andui ugari neutralizatuko dituzten bNab-en erantzuna lortu, sekuentzia kontserbazio maila altua duten peptido laburretan oinarritutako txertoak garatuz. Honen adibide da MPER domeinuaren aurkako txertoen garapena. Izan ere, eskualde hau oso kontserbatua dago eta birus espektro zabala neutralizatzeko gai den 10E8 bNab-aren epitopoa du. Mintzaren gainazalean kokatuta dagoen eta aminoazido aromatikoetan aberatsa den sekuentzia duenez $[10,46]$, eskualde honen inguruan egindako azterketen emaitzek iradokitzen dute MPER domeinuan oinarritutako txertoak garatzeko, beharrezkoa izan daitekeela mintza imitatzen duen ingurugiro bat; hori dela eta, eremu honetan oinarritutako txertoak ingurune lipidiko batekin konbinatzen dira normalean, liposomekin adibidez [47].

Orain arte esan legez, erronka handia da immunogeno bakar batez antigorputz neutralizatzaileen sintesia piztea; izan ere, bNab-ak infekzio naturalean birusarekin ko-eboluzionatu dutelarik mutazio asko pairatu dituzten antigorputz oso bereziak dira [48, 49]. Beraz, antigorputzek infekzioan zehar jasaten duten eboluzioa imitatzeko helburuarekin hainbat immunogeno erabilitzea metodo egokia izan daiteke txerto eraginkor bat 
lortzeko [50]. Immunogeno hauen diseinurako, bNab-ak ekoiztuko dituen B linfozito aitzindariak zein $\mathrm{V}(\mathrm{D}) \mathrm{J}$ geneen segmentuak errekonbinatu dituen eta baita bNab horretara heltzeko segmentu hauetan gertatu diren mutazioak ere ezagutu beharko lirateke; hau da, ko-eboluzioa pausuz pausu nolakoa izan den aztertu beharko genuke. Beraz, eboluzio-urrats bakoitzean ekoizten den antigorputza aztertu eta harentzako immunogeno egokia diseinatu beharko litzateke. Estrategia honen adibide da eOD-GT8 molekula, VRC01 motako antigorputz neutralizatzaileak ekoizten dituzten B zelula germinal aitzindariak aktibatzen dituena hain zuzen ere [48]. Immunogeno honek bakarrik, ez du antigorputz neutralizatzaileen sintesia eragingo; horretarako, bNab-en ontogenian sortutako gainontzeko antigorputzentzat diseinatu beharko dira immunogenoak [51]. Tamalez, bNab askoren kasuan, B linfozitoen ontogenia ez da ezagutzen; izan ere, laginak infekzioa gertatu eta urte asko igaro ostean lortu dira, eta galdu egin da hasierako urratsetako informazioa. Hori dela eta, metodo konputazionalen laguntza behar da, urrats bakoitzeko antigorputzen izaera genetikoa zehazteko, finkatzeko. Frogatzeke dago hala ere analisi konputazionalen bitartez lorturiko informazio honen fidagarritasuna eta metodoaren baliotasuna.

Estrategia hauen guztien egokigarritasuna agerian uzteko, animaliaeredu egokiak behar dira, immunizazio saioen bitartez, antigorputzen bidezko erantzuna aztertu ahal izateko. Orain arte, animalia-eredu moduan, saguak eta untxiak erabili izan dira besteak beste, baina bNab-ek dituzten ezaugarri bereziak direla eta, murriztapen ugari dituzte haien ekoizpen egokia egiteko. Adibidez saguek, ez dute egiten CDR-H3 eskualde luzeak dituzten antigorputzen ekoizpena [52]. Gainera, baliteke espezie hauetan ez egotea bNab-ak ekoizten dituzten B zelula germinal aitzindariak. Horrenbestez, gaur egun garrantzia handia hartzen ari diren animalia-ereduak giza antigorputzak adierazten dituzten saguak (bNab knock-in saguak alegia, KI saguak) [53] eta sagu humanizatuak dira [54].

Eredu hauetan oinarrituta egindako ikerketak, gizakietan edo primateetan egindako azterketekin osatu behar dira, baina nahiko informazio ematen dute B zelulen aukeraketa eta eraketaren inguruan, baita immunogeno berriek antigorputzen ekoizpenean izan dezaketen erantzunaren inguruan ere $[35,53]$.

\section{ONDORIOAK}

GIBak 2 milioi indibiduo inguru hiltzen ditu urtean eta egunero 7.000 infektatzen dira. Gaur egun, birus honi aurre egiteko terapia antirretrobirala erabiltzen da, baina HIESaren pandemiari amaiera emateko, ezinbestekoa da txerto profilaktiko bat garatzea. Bere identifikazioa egin zene- 
tik 30 urte baino gehiago igaro dira eta saiakera ugari egin dira baina hain birus aldakorra delarik, ez da oraindik honen aurkako txerto profilaktorik garatu. Hala ere, bNab-en existentziak eta RV144 entseguak izandako arrakastak iradokitzen dute GIBaren aurkako txerto baten garapena posiblea dela. Helburu hau lortu ahal izateko aurrerako pausu handiak eman dira baina, oraindik ere etorkizunerako erronka ugari daude.

Alde batetik, ezinbestez sakondu behar da infekzioa gertatutakoan immunitate-sistemak abian jartzen dituen mekanismoen ikasketan. Esaterako, oso garrantzitsua da $\mathrm{B}$ eta $\mathrm{T}$ linfozitoen erantzuna pizteko eta mantentzeko zein baldintzak bete behar diren ulertzea. Esaterako, elitezko kontrolatzaileen inguruko ikerketa sakona egin behar da, tratamendurik jaso gabe birusarekin bizitzen diren indibiduo hauek dituzten berezitasunak ulertzeko $[31,54]$.

Sistema immuneak dituen mekanismoez gain, ezibestekoa da era berean immunogeno egokien diseinurako, bNab-en ezaugarri funtzionalak, egitura, heltze prozesua eta Env konplexuarekin dituen elkarrekintzetan gehiago sakontzea. Orain arte, RV144 entsegua alde batera utzita, beste entsegu guztiek arrakasta eskasa izan dute, eta hori ikusita badirudi immunogenoen diseinurako ezinbestekoak direla estrategia berritzaileak, hala nola, azkenaldian ikertzen hasi diren estrategia: hain zuzen, bNab-en B zelula germinal aitzindaria immunogeno batez piztea eta Env konplexua imitatzen duten beste immunogeno batzuen bitartez antigorputzen heltze prozesua bideratzea. Oraindik ordea, lan handia dago B zelula aitzindari germinalen erantzuna pizten duten immunogenoen egitura ulertzeko, baita Env konplexuan dauden epitopo desberdinek sistema immunean eragiten duten erantzuna aztertzeko [50]. Behin immunogeno berriak diseinatuta, animalia-eredu egokiak zein txertaketa-estrategia egokiak aukeratu beharko dira.

Azkenik, esan beharra dago azken urte hauetan aurerrakuntza handiak egin direla txertaketa-estrategia desberdinen eta antigorputz neutralizatzaileen inguruan, eta horren ondorioz eskuragarriago dagoela pandemia den HIESari amaiera eman liezaiokeen txerto prebentibo eta eraginkor baten garapenaren ametsa.

\section{ESKER ONAK}

Lan hau aurrera eramateko honako erakundeen laguntza jaso dugu: Biofisika Bizkaia Fundazioa eta UPV/EHU. 
GIBaren aurkako txertoaren bila

\section{BIBLIOGRAFIA}

[1] http://aidsinfo.unaids.org/ 2017-06-23

[2] https://www.fda.gov/forpatients/illness/hivaids/treatment/ucm118915.htm 2016-09-08

[3] http://www.who.int/hiv/pub/guidelines/arv2013/intro/rag/en/ 2017-06-23

[4] DE FEO, C. J. eta WEISS, C. D. 2012. «Escape from human immunodeficiency virus type 1 (HIV-1) entry inhibitors. » Viruses, 4, 3859-3911.

[5] JULIEN, J. P., CUPO, A., SOK, D., STANFIELD, R. L., LYUMKIS, D., DELLER, M. C., WILSON, I. A. 2013. «Crystal structure of a soluble cleaved HIV-1 envelope trimer. » Science, 342, 1477-1483.

[6] LYUMKIS, D., JULIEN, J. P., DE VAL, N., CUPO, A., POTTER, C. S., KLASSE, P. J., WARD, A. B. 2013. «Cryo-EM structure of a fully glycosylated soluble cleaved HIV-1 envelope trimer. » Science, 342, 1484-1490.

[7] APELLANIZ, B., IVANKIN, A., NIR, S., GIDALEVITZ, D. eta NIEVA, J. L. 2011. «Membrane-proximal external HIV-1 gp41 motif adapted for destabilizing the highly rigid viral envelope. » Biophys J, 101, 2426-2435.

[8] APELLANIZ, B., RUJAS, E., SERRANO, S., MORANTE, K., TSUMOTO, K., CAAVEIRO, J. M., NIEVA, J. L. 2015. «The Atomic Structure of the HIV-1 gp41 Transmembrane Domain and Its Connection to the Immunogenic Membrane-proximal External Region.» J Biol Chem, 290, 12999-13015.

[9] LORIZATE, M., HUARTE, N., SAEZ-CIRION, A. eta NIEVA, J. L. 2008. «Interfacial pre-transmembrane domains in viral proteins promoting membrane fusion and fission. » Biochim Biophys Acta, 1778, 1624-1639.

[10] SALZWEDEL, K., WEST, J. T. eta HUNTER, E. 1999. «A conserved tryptophan-rich motif in the membrane-proximal region of the human immunodeficiency virus type $1 \mathrm{gp} 41$ ectodomain is important for Env-mediated fusion and virus infectivity. » $J$ Virol, 73, 2469-2480.

[11] BRUGGER, B., GLASS, B., HABERKANT, P., LEIBRECHT, I., WIELAND, F. T. eta KRAUSSLICH, H. G. 2006. «The HIV lipidome: a raft with an unusual composition. » Proc Natl Acad Sci U S A, 103, 2641-2646.

[12] CAMPBELL, S. M., CROWE, S. M. eta MAK, J. 2002. «Virion-associated cholesterol is critical for the maintenance of HIV-1 structure and infectivity.» AIDS, 16, 2253-2261.

[13] https://commons.wikimedia.org/wiki/File:HIV-replication-cycle-en.svg 2017-06-20

[14] KWONG, P. D. eta MASCOLA, J. R. 2012. «Human antibodies that neutralize HIV-1: identification, structures, and B cell ontogenies. » Immunity, 37, 412-425.

[15] LEE, J. H., OZOROWSKI, G. eta WARD, A. B. 2016. «Cryo-EM structure of a native, fully glycosylated, cleaved HIV-1 envelope trimer. » Science, 351, 1043-1048.

[16] RUJAS, E., CAAVEIRO, J. M., PARTIDA-HANON, A., GULZAR, N., MORANTE, K., APELLANIZ, B., NIEVA, J. L. 2016. «Structural basis for 
broad neutralization of HIV-1 through the molecular recognition of 10E8 helical epitope at the membrane interface. » Sci Rep, 6, 38177.

[17] DEV, J., PARK, D., FU, Q., CHEN, J., HA, H. J., GHANTOUS, F., CHOU, J. J. 2016. «Structural basis for membrane anchoring of HIV-1 envelope spike. » Science, 353, 172-175.

[18] http://www.who.int/immunization/diseases/en/ 2017-06-23

[19] ESPARZA, J. 2013. «A brief history of the global effort to develop a preventive HIV vaccine. » Vaccine, 31, 3502-3518.

[20] SLIFKA, M. K. eta AMANNA, I. 2014. «How advances in immunology provide insight into improving vaccine efficacy. » Vaccine, 32, 2948-2957.

[21] PLOTKIN, S. 2014. «History of vaccination. » Proc Natl Acad Sci U S A, 111, $12283-12287$.

[22] MOODY, M. A. 2014. «Modulation of HIV-1 immunity by adjuvants.» Curr Opin HIV AIDS, 9, 242-249.

[23] PICKER, L. J., HANSEN, S. G. eta LIFSON, J. D. 2012. «New paradigms for HIV/AIDS vaccine development. » Annu Rev Med, 63, 95-111.

[24] ACHARYA, P., LUSVARGHI, S., BEWLEY, C. A. eta KWONG, P. D. 2015. «HIV-1 gp120 as a therapeutic target: navigating a moving labyrinth. » Expert Opin Ther Targets, 19, 765-783.

[25] SAUNDERS, K. O., RUDICELL, R. S. eta NABEL, G. J. 2012. «The design and evaluation of HIV-1 vaccines. » AIDS, 26, 1293-1302.

[26] CHEN, L., KWON, Y. D., ZHOU, T., WU, X., O'DELL, S., CAVACINI, L., KWONG, P. D. 2009. «Structural basis of immune evasion at the site of CD4 attachment on HIV-1 gp120. » Science, 326, 1123-1127.

[27] HU, G., LIU, J., TAYLOR, K. A. eta ROUX, K. H. 2011. «Structural comparison of HIV-1 envelope spikes with and without the V1/V2 loop. » $J$ Virol, 85, 2741-2750.

[28] ZHU, P., CHERTOVA, E., BESS, J., JR., LIFSON, J. D., ARTHUR, L. O., LIU, J., ROUX, K. H. 2003. «Electron tomography analysis of envelope glycoprotein trimers on HIV and simian immunodeficiency virus virions. » Proc Natl Acad Sci U S A, 100, 15812-15817.

[29] BURTON, D. R. eta MASCOLA, J. R. 2015. «Antibody responses to envelope glycoproteins in HIV-1 infection. » Nat Immunol, 16, 571-576.

[30] KWONG, P. D., DOYLE, M. L., CASPER, D. J., CICALA, C., LEAVITT, S. A., MAJEED, S., ARTHOS, J. 2002. «HIV-1 evades antibody-mediated neutralization through conformational masking of receptor-binding sites.» Nature, 420, 678-682.

[31] LEMA, D., GARCIA, A. eta DE SANCTIS, J. B. 2014. «HIV vaccines: a brief overview. »Scand J Immunol, 80, 1-11.

[32] HAYNES, B. F., MOODY, M. A., VERKOCZY, L., KELSOE, G. eta ALAM, S. M. 2005. «Antibody polyspecificity and neutralization of HIV-1: a hypothesis. » Hum Antibodies, 14, 59-67.

[33] KELSOE, G. eta HAYNES, B. F. 2017. «Host controls of HIV broadly neutralizing antibody development. » Immunol Rev, 275, 79-88. 
[34] GAUTAM, R., NISHIMURA, Y., PEGU, A., NASON, M. C., KLEIN, F., GAZUMYAN, A., MARTIN, M. A. 2016. «A single injection of anti-HIV-1 antibodies protects against repeated SHIV challenges. » Nature, 533, 105-109.

[35] GRUELL, H. eta KLEIN, F. 2017. «Progress in HIV-1 antibody research using humanized mice. » Curr Opin HIV AIDS, 12, 285-293.

[36] BABA, T. W., JEONG, Y. S., PENNICK, D., BRONSON, R., GREENE, M. F. eta RUPRECHT, R. M. 1995. «Pathogenicity of live, attenuated SIV after mucosal infection of neonatal macaques. » Science, 267, 1820-1825.

[37] PITISUTTITHUM, P., GILBERT, P., GURWITH, M., HEYWARD, W., MARTIN, M., VAN GRIENSVEN, F., BANGKOK VACCINE EVALUATION, G. 2006. «Randomized, double-blind, placebo-controlled efficacy trial of a bivalent recombinant glycoprotein $120 \mathrm{HIV}-1$ vaccine among injection drug users in Bangkok, Thailand. » J Infect Dis, 194, 1661-1671.

[38] FLYNN, N. M., FORTHAL, D. N., HARRO, C. D., JUDSON, F. N., MAYER, K. H., PARA, M. F. eta RGP, H. I. V. V. S. G. 2005. «Placebocontrolled phase 3 trial of a recombinant glycoprotein 120 vaccine to prevent HIV-1 infection. » J Infect Dis, 191, 654-665.

[39] COHEN, K. W. eta FRAHM, N. 2017. «Current views on the potential for development of a HIV vaccine. » Expert Opin Biol Ther, 17, 295-303.

[40] HAMMER, S. M., SOBIESZCZYK, M. E., JANES, H., KARUNA, S. T., MULLIGAN, M. J., GROVE, D., TEAM, H. S. 2013. «Efficacy trial of a DNA/rAd5 HIV-1 preventive vaccine. » N Engl J Med, 369, 2083-2092.

[41] RERKS-NGARM, S., PITISUTTITHUM, P., NITAYAPHAN, S., KAEWKUNGWAL, J., CHIU, J., PARIS, R., INVESTIGATORS, M.-T. 2009. «Vaccination with ALVAC and AIDSVAX to prevent HIV-1 infection in Thailand. » N Engl J Med, 361, 2209-2220.

[42] HE, L., DE VAL, N., MORRIS, C. D., VORA, N., THINNES, T. C., KONG, L., ZHU, J. 2016. «Presenting native-like trimeric HIV-1 antigens with self-assembling nanoparticles. » Nat Commun, 7, 12041.

[43] INGALE, J., STANO, A., GUENAGA, J., SHARMA, S. K., NEMAZEE, D., ZWICK, M. B. eta WYATT, R. T. 2016. «High-Density Array of WellOrdered HIV-1 Spikes on Synthetic Liposomal Nanoparticles Efficiently Activate B Cells. » Cell Rep, 15, 1986-1999.

[44] CROOKS, E. T., TONG, T., OSAWA, K. eta BINLEY, J. M. 2011. «Enzyme digests eliminate nonfunctional Env from HIV-1 particle surfaces, leaving native Env trimers intact and viral infectivity unaffected. » $J$ Virol, 85, 5825-5839.

[45] TONG, T., CROOKS, E. T., OSAWA, K. eta BINLEY, J. M. 2012. «HIV-1 virus-like particles bearing pure env trimers expose neutralizing epitopes but occlude nonneutralizing epitopes. » $J$ Virol, 86, 3574-3587.

[46] SUAREZ, T., GALLAHER, W. R., AGIRRE, A., GONI, F. M. eta NIEVA, J. L. 2000. «Membrane interface-interacting sequences within the ectodomain of the human immunodeficiency virus type 1 envelope glycoprotein: putative role during viral fusion. » $J$ Virol, 74, 8038-8047. 
[47] APELLANIZ, B. eta NIEVA, J. L. 2015. «The Use of Liposomes to Shape Epitope Structure and Modulate Immunogenic Responses of Peptide Vaccines Against HIV MPER. » Adv Protein Chem Struct Biol, 99, 15-54.

[48] WU, X., YANG, Z. Y., LI, Y., HOGERKORP, C. M., SCHIEF, W. R., SEAMAN, M. S., MASCOLA, J. R. 2010. «Rational design of envelope identifies broadly neutralizing human monoclonal antibodies to HIV-1. » Science, 329, 856-861.

[49] NIEVA, J. L., APELLANIZ, B., HUARTE, N. eta LORIZATE, M. 2011. «A new paradigm in molecular recognition? Specific antibody binding to membrane-inserted HIV-1 epitopes. » J Mol Recognit, 24, 642-646.

[50] JARDINE, J. G., OTA, T., SOK, D., PAUTHNER, M., KULP, D. W., KALYUZHNIY, O., NEMAZEE, D. 2015. «HIV-1 VACCINES. Priming a broadly neutralizing antibody response to HIV-1 using a germline-targeting immunogen. » Science, 349, 156-161.

[51] MOORE, P. L., GORMAN, J., DORIA-ROSE, N. A. eta MORRIS, L. 2017. «Ontogeny-based immunogens for the induction of V2-directed HIV broadly neutralizing antibodies. » Immunol Rev, 275, 217-229.

[52] WU, T. T., JOHNSON, G. eta KABAT, E. A. 1993. «Length distribution of CDRH3 in antibodies. » Proteins, 16, 1-7.

[53] VERKOCZY, L., ALT, F. W. eta TIAN, M. 2017. «Human Ig knockin mice to study the development and regulation of HIV-1 broadly neutralizing antibodies. » Immunol Rev, 275, 89-107.

[54] SIMEK, M. D., RIDA, W., PRIDDY, F. H., PUNG, P., CARROW, E., LAUFER, D. S., KOFF, W. C. 2009. «Human immunodeficiency virus type 1 elite neutralizers: individuals with broad and potent neutralizing activity identified by using a high-throughput neutralization assay together with an analytical selection algorithm. » $J$ Virol, 83, 7337-7348. 